\title{
Reconciling theory and practice on the participation of the downtrodden in poverty intervention policies and programs
}

\author{
Abu Idris ${ }^{1}$, Rohana Yusof ${ }^{2}$ \\ ${ }^{1}$ (College of Law and Government International School (COLGIS), Universiti Utara Malaysia). \\ ${ }^{2}$ (Northern Corridor Research Centre, College of Business Studies (NCRC), Universiti Utara Malaysia).
}

\begin{abstract}
The advocacy for the inclusion of community participation in policy process and consideration for the vox populi (voice of the people) in poverty intervention policies and programs has become a global mantra., Albeit, there are dearth of study that integrates theory and practice of participation to empirically test the effect of participation of the downtrodden on policies that affect them. This paper adopts mixed method to relate the theory and practice vis-a-vis examine the efficacy of participation of the downtrodden in poverty intervention programs in Niger state rural area. The quantitative findings indicate significant relationship between participation of the downtrodden in policy initiation and poverty reduction, while the qualitative result reveals that participation is theoretically faultless but empirically faulty-it is elite dominating and more of indoctrination, political gimmick, deceit, pretense, and mere formality than reality. Resolutions where neither reflected in the policy agenda nor implemented. Consequently, participation of the downtrodden in policy is not suffice to alleviate poverty, thus, the study recommends for legal empowerment of an instituted advocacy group, featuring the Non-governmental organizations (NGOs) in the like of Civil Society Organization (CSO), dominant beneficiaries of intervention programs and stakeholders to checkmate the assumed excessive power of all and sundry connected to the intervention programs.
\end{abstract}

Keywords: Downtrodden, intervention, participation, practice, theory

\section{INTRODUCTION}

Participation has become a global mantra in the development agenda and used by politicians in the political arena (Penderis, 2012) to sway the electorates. As a result of its global recognition, citizens in developed and developing nations are gaining inspirations and experiences on collaborative governance, citizens' advisory committees, and participatory budgeting (Cain, Dalton, \& Scarrow, 2003; Michels \& De Graaf, 2010). Scholars considers citizen participation as a valuable component of democratic citizenship and decision-making processes (Michels \& De Graaf, 2010). Ferragina, Tomlinson, and Walker (2013) recognized democratic setting as an avenue that authorize citizens to decide and identify their felt-needs devoid of individual opportunist imposing their egoistic desires on the citizens. Considering the importance of participation, Townsend argue that, poverty is less about scarcity of income and more about the inability of low income earners to participate actively in policies that affect them. Presumably, the involvement of the vulnerable citizen and potential beneficiaries of intervention schemes in policy articulation and implementation is one of the approaches for the sustainability of policies and programs and improvement of their wellbeing (Cleaver, 1999). Tolerating a more inclusive participatory policy process has the tendency to reverse the top-down nuisance of hostile intervention program(s) and subsequently improve citizens' participation to alleviate rural poverty (Ahmad, Abdullah, \& Arshad, 2015).

Conversely, studies reveal that participation of the downtrodden in poverty intervention agenda is a mere utopia and does not reflect the true objectives of the programs. This scenario explain the solitarily formulation and implementation of policies and programs by the government without consulting the target beneficiaries (Aminu \& Onimisi, 2014). The advocacy for inclusive of community participation in poverty intervention policies and programs has become world slogan. Albeit, there are dearth of study that actively integrated theory and practice of participation to empirically test the effect of participation of the downtrodden on policies that directly affect them consequently, identifying a chasm for further studies. Erstwhile studies on participatory policy focused on the relationships between citizens and government (Lowndes \& Sullivan, 2004; Michels \& De Graaf, 2010). Others determined the efficacy of community participation as an effective policymaking instrument (Irvin \& Stansbury, 2004), factors affecting farmers' participation in agricultural projects and how participation, empowerment and poverty reduction is perceived in the international development policy among others (Alejandro Leal, 2007; Nxumalo \& Oladele, 2013). Based on the foregoing presuppositions, this study intends to bridge the theoretical and empirical gaps on the downtrodden participation in policy 
formulation and implementation on National Fadama Development III (NFDPIII), Niger state commercial agricultural credit scheme (NSCACS) and National Poverty Eradication program (NAPEP) all in Niger state.

\section{METHODOLOGY}

This study adopts mixed method, using questionnaire instrument to collect a cross sectional data from 18 rural communities in 9 local government areas of Niger state to determine the efficacy of participation of the downtrodden on three intervention programs. 440 structured questionnaires were administered on the respondents and 347 were valid for analysis. An in-depth face to face interview and Focus Group Discussion was conducted on 19 informants (Stakeholders representing the government officials and beneficiaries of the programs) to validate the quantitative results. The study adopts probability sampling method which tolerate each item of the population the equal chance of being selected as a sample to curtail high rate of prejudice (Sekaran \& Bougie, 2014). Explicitly, we used multi-stage sampling technique, where Niger state as a study area was grouped into three senatorial districts. Partial Least Square (PLS) was used to establish the statistical relationship between participation of the beneficiaries in the poverty intervention programs and poverty reduction. Besides, measurement of this study was adapted from the studies of (IFAD, 2000; Mango, 2010; Mucunguzi, 2011 with slight contextual adjustment that suit the study area vis-a-vis to measure the independent and dependent variables using 5 likert scale.

\section{Theory of Participation}

\section{LITERATURE REVIEW}

The misgivings of orthodox development theories in the late 1960s and their inability to address the conundrum of poverty across the globe facilitates the systematic search for an alternate theoretical analyses and a paradigm shift from economic growth to social development. Within the neighborhood of 1970s and 1980s, participatory approaches were metaphorically perceived as a "child of necessity" to development practice and progressively upheld people-centered development, state society synergies, participatory democracy and grassroots development (Maiava, 1995; Potts, Awuzie, McDermott, \& Stephenson, 2015; Rahman, 1993).

Participatory theory is a conceptual framework which attempts to bridge the subject distinction. Participatory approaches to poverty research recognizes the specific group of people with experience of poverty to put forward their realities (Lewis, 2008). The arguments in favor of participatory approaches in poverty study emphasize the value of improving the quality of research and its potency on the vulnerable. Thus, the kernel of participatory notion is a turn from intra-subjective experiences to participatory events in our understanding of transpersonal and spiritual phenomena (Ferrer, 2002). By implication, people-centered development discourse accentuates that people should be the planners of their own future (Al Attar, 2015; Burkey, 1993; Mandal \& Jirli, 2016; Oakley, 1991) concentrating on the role of social capital, competences, liberty and the skill of common people to cope with development strategies (Dreze \& Sen, 1999; Sen, 1999). Within this view, participatory development enable the poor to influence, implement and control activities which are essential to their development through interaction with agencies, officials and technical consultants (Burkey, 1993; Chambers, 2002). Participatory approaches during the 1980s recognized the value of generating local knowledge and empowering beneficiaries of development efforts to partake in all phases of the process (Brownhill, Moturi, \& Hickey, 2016; Hickey \& Mohan, 2004, 2005).

Upholding the positions of the scholars, government entities enact laws, policies and allocate resources to serve as an operational guide to its daily routines. Traditionally, policy decision and obligation for articulating and implementing participatory development policies and programs rest with the governments of individual countries. This prompted the formation of participatory institutes and collaborating units to facilitate interaction between the state and society vis-a-vis employ mutually reinforcing means to address societal challenges especially among the downtrodden (Penderis, 2012; Siphuma, 2009).

Policy formulation and implementation in the public institutions has recently been transformed from focusing on the one-sided regulatory decision to a more comprehensive and wide-ranging process that encompasses stakeholders and the recipients of the policy in both rural and urban centers, rich or poor (Jami \& Walsh, 2014). Patel and Mitlin (2002) declared that participation process is a transformational apparatus for social change, better decision and efficient services to the society. Participation in decision making provides avenues for cross-fertilization of idea (Tschirhart et al., 2016) as it enable the citizen acquires skills to challenge or persuade the government where necessary; and conversely, government persuades its citizens, builds trust and calm anxiety or hostility to strike a balance vis-à-vis give room for harmonious relationship with the citizens towards societal development .

Albeit, a number of scholars opined that the concept of participation is equivocal and value-laden, restricted by theoretical confusion, time constrictions, and poor foundation in development theory (Penderis, 
2012). It is arguing that practitioners and theorists are gradually emphasizing its relegation and disruptive powers through its robotic use as an instrument to certify pre-conceived policy initiatives. In spite of this critique, O'Toole (2000) opined that success of any intervention policy requires the recognition or involvement of a number of actors, many organizations and the dominant role of recipients/beneficiaries to expedite result accomplishment. In this context, the actors consist of the stakeholders, the target beneficiaries and even the civil societies. Thus, the practice and recognition of participatory approaches as an ultimate key for the challenges facing developing nations is unabated (Penderis, 2012). The top-down approach was faulted on the ground that it fails to reflect the importance of past actions in the same policy area; disregard implementation as an administrative process and ignores the talent of local implementers but consider them as obstacles to implementation processes. On that premise, bottom-up models was advanced based on the criticism of top-down models which ignored the behavioral side of implementation and the roles of local implementers (Scheingold, 2010).

The participation of the downtrodden in intervention programs encapsulate the philosophy of bottomup approach. Cerna (2013) acknowledged that, bottom-up approach largely focus on the target groups and service deliverers and it is a situation that policy formulation tolerates the contribution of the beneficiaries. The model is perceived to be descriptive in nature and circumstances where implementation can be better appreciated by considering the policy from the viewpoint of target groups. For instance, a study reveals that farmers' participation in agricultural projects has a direct bearing on technology awareness, adoption, livelihoods, environment, and nutrition vis-a-vis poverty reduction (Etwire et al., 2013). A farming institute that adopts the top-bottom strategy with little input and commitment of farmers have been identified as an unsustainable and weak trajectory to farmers' active participation in policy formulation and implementation and subsequently explains the low yield and productivity in Ethiopian agriculture (Etwire et al., 2013). Bureaucratic bottleneck, high transport cost to the venue of meeting and above all low awareness (Akpan \& Udoh, 2016) are perceived as major constraints to farmers' participation in poverty intervention programs. Confirming the above assertions, researchers maintained that a number of policies and programs have been employed by the government to address different kinds of teething phenomenon in Nigeria, such as poverty, desertification, yet, the problems persists as a result of prevailing gap(s). For instance strategies to resolving the issues has been handled by an individual or region instead of integrating or incorporating all and sundry to jointly proffer solutions to the problems (Idris, Rafee, \& Johar, 2011; Thelma, 2015).

Sometimes in 1990s, the administrative system of Uganda was exceedingly centralized (top-bottom), with the mainstream of the policy making and implementation taking place in the Federal government (OnyachOlaa \& Porter, 2000), consequently, stakeholders unanimously agitates for revolution of top-down approach which compelled the institution of decentralization. It is important to note that centralized administration inspires duplication of effort, operational ineptitudes, and waste of resources, and above all, undemocratic for the fact that government decisions were made without the input of the popular beneficiaries from the grassroots (Nielsen, 2008). Obadan (2001) maintained that effort en-route for poverty alleviation as articulated in the rudimentary objectives of development plan of Nigeria overlooked policies and programs that directly targeted the rural poor, so, the conditions of the poor deteriorated despite the growth of the economy. In the same vein, Aminu and Onimisi (2014) pointed out that the acceptance of top-bottom approach in the formulation and implementation of poverty alleviation program worsened the situation in Nigeria, because the target beneficiaries who mostly reside in the rural areas were marginalized as a result of the fact that the activities or programs that alleviate poverty only focused on the state and local government headquarters. Considering the roles of participation of the target beneficiaries, we hypothesized that participation of target beneficiaries in policy formulation and implementation is positively related to poverty alleviation in Niger State rural areas. However, participatory approach was criticized because it focuses much attention on the autonomy of the downtrodden whereas plan control requires to be done by actors whose influence to formulate policies is derived by virtue of being elected representatives. Additionally, it is possible to influence the goals and strategies of the downtrodden by influencing their institutional structure, the resources made available to them and approachability to the real implementation arena (Schofield, 2001).Several poverty reduction initiatives introduced in Ghana have negligible bearing on the poor farming communities. This was as a result of side-line of the target beneficiaries in the process of policy formulation. Therefore, adoption of bottom-top approach was recommended in the formulation of poverty reduction programs and to feature the downtrodden into the equation particularly that agriculture is the dominant employer of the downtrodden in Ghana (Ameyaw \& Nyigmah, 2009; Bawole \& Hossain; Domfeh, Ahenkan, \& Bawole, 2012; Roy Kartik \& Tisdell, 1998; Selebalo, 2001).

Remarking from a different angle, Forae and Benedict (2011) contends that policy failure on poverty alleviation is not only associated to top-down or bottom-up approaches alone but connected to misunderstanding of the suitable policy for the target beneficiaries, illogical priorities, discrimination and self-benefit that breeds 
disapproval for the policy. The authors upheld that inaccurate data or poor knowledge about the beneficiaries, particularly their felt-needs could lead to either overestimation or underestimation of the phenomenon, thus, the prevalent conditions on poverty alleviation policies will be in incongruity with peoples' demand. For instance, poverty alleviation policies focused on unemployment at the detriment of mass poverty threatening the rural areas could not adequately address poverty problems. At all stages of government, citizen participation programs were introduced with the assumptions that citizen become enthusiastically involved as participants in their democracy, hence, the government or leadership that arose from this process would be more democratic and effective (Francis \& James, 2003). Opinions on enhanced citizen participation time and again based on merits of the process and the view that an involved citizen is superior than a passive citizen (Irvin \& Stansbury, 2004; King, 1998).

\section{RESULT AND DISCUSSION}

Measurement model

Measurement model valuation is central to introduce the validity and reliability of the data. The canon of composite reliability suggests that indicators have unique loadings and can be taken to mean in the same way as Cronbach's alpha. In order to establish the reliability and validity of measures, individual item reliability, internal consistency reliability, convergent validity and discriminant validity were visibly measured (Hair Jr, Hult, Ringle, \& Sarstedt, 2013). The table below displays the composite reliability coefficients of the variables. The composite reliability coefficient for PARTICIPATION (PAR) is 0.861 while POVERTY ALLEVIATION (PAL) is .953. This entails that each exceed the acceptable threshold of .70 demonstrating suitable internal consistency reliability of the measures used in this study (Hair, Ringle, \& Sarstedt, 2011). Nonetheless, it is important to appreciate that the analysis of the outer model led to the deletion of 7 indicators out 27 indicators. In order to define the convergent validity, the Average Variance Extracted (AVE) for each of the variables were examined and found to exceed 0.50 (Bagozzi \& Yi, 1988; Hair Jr et al., 2013) as shown in Table 1 below hence, signifying satisfactory convergent validity.

Table1 Item loadings AVE and reliabilities

\begin{tabular}{lcccc}
\hline Code & Loadings & AVE & $\begin{array}{c}\text { Composite } \\
\text { Reliability }\end{array}$ & Cronbach Alpha \\
PAL01 & .784 & .577 & .953 & .947 \\
PAL02 & .706 & & & \\
PAL03 & .764 & & & \\
PAL04 & .788 & & \\
PAL05 & .787 & & \\
PAL06 & .746 & & \\
PAL07 & .721 & & \\
PAL09 & .663 & & \\
PAL10 & .717 & & \\
PAL11 & .848 & & \\
PAL12 & .861 & & \\
PAL14 & .769 & & \\
PAL15 & .750 & & \\
PAL16 & .794 & & \\
PAL17 & .672 & & \\
PAR03 & .808 & & \\
PAR05 & .728 & & \\
PAR08 & .717 & & \\
PAR09 & .691 & & \\
PAR10 & .774 & & \\
\hline Computation & & & \\
\hline
\end{tabular}

Source: Computation 
Table 2 Direct relationship

Hypotheses test

\begin{tabular}{clccccl}
\hline Hypotheses & Relationships & Beta value $(\boldsymbol{\beta})$ & $\begin{array}{c}\text { Standard } \\
\text { Error }\end{array}$ & $\begin{array}{c}\text { T } \\
\text { value }\end{array}$ & P value & Decision \\
\hline H1 & PAR -> PAL & .076 & .039 & 1.963 & $0.03^{* *}$ & Supported \\
\hline
\end{tabular}

$* * * \mathrm{p}<0.01, * * \mathrm{p}<0.05, * \mathrm{p}<0.10$
In line with the formulated hypothesis that participation of target beneficiaries in policy formulation and implementation is related to poverty alleviation in Niger state rural areas. The result reveals significant relationship between participation of beneficiaries in policy initiation and poverty reduction where: $\beta=.076, \mathrm{t}=$ $1.963, \mathrm{p}=0.03$ thereby validating our hypothesis and consequently consistent with earlier studies (Aboh \& Onabe, 2007; Akinola, 2013; Cornwall \& Brock, 2005; DFID, 2005; Ephraim, 2013; Nxumalo \& Oladele, 2013; Okafor, 2015; Olomola, 2013).

Table3 Demographic data

\begin{tabular}{lll}
\hline Categories & Frequency & Percentage \\
\hline Gender & 261 & 75.2 \\
Male & 86 & 24.8 \\
Female & & \\
Age & 54 & 15.6 \\
$15-25$ years & 74 & 21.3 \\
$26-35$ years & 78 & 22.5 \\
$36-45$ years & 84 & 24.2 \\
$46-55$ years & 57 & 16.4 \\
56 and above years & & \\
Occupation & 12 & 3.5 \\
Civil Service & 318 & 91.6 \\
Farming & 14 & 4.0 \\
Business (Trade) & 3 & 0.9 \\
Others & & \\
\hline
\end{tabular}

Source: computation

Table 3 above account the demographic data of the respondents in this study. Gender distributions of the respondents are lopsided with male population leading with 261 signifying 75.2 percent and 86 female equals to 24.8 percent of the total respondents. Ages were being in range and measured in years and the result demonstrates that 54(15.6 percent) of respondents were within $15-25$ years, whereas 74 (21.3 percent) fall into the age bracket of $26-35$ years. This was followed by $36-45$ years representing 78 (22.5 percent) participants. However, the uppermost category of the respondents is 84 representing 24.2 percent the least age range (56 and above) has 57 participants paralleled to 16.4 percent. The demographic particulars indicate that 12 (3.5 percent) respondents were civil servants, 318 (91.6 percent) were primarily farmers which signify that mainstream of the respondents in this study were rural farmers. In the same vein, 14(4 percent) were businessmen and women other respondents 3 ( 0.9 percent) were mute on their professions.

Participation epitomized genuine acceptance of the authorized people to keenly partake in decisions that affect them (Cornwall, 2000). Indications from varied literature and particularly the quantitative survey above attests that participation has significance impact on poverty reduction (Cornwall, 2000; Cornwall \& Brock, 2005). Accordingly, the World Bank affirms that if the government desires to end poverty, then the poor should not be relegated, but integrated in the course of planning their individual development; so also, if the desired societal transformation is to be achieved, citizens must be embedded in decision that affect them; as participation entails "work with the people" rather than "work for the people"(Cammack, 2004; Cornwall, 2000).

The study analyses the feelings of nine (9) stakeholders for the interview conducted and ten (10) beneficiaries for Focus Group Discussion (FGD). Pseudonyms were used throughout, with real names of informants 
preserved. Therefore, the duo was represented in the study as "informants" based on the pledge made to maintain high degree of confidentiality of the interviewees and also respect their privacy. To differentiate among the anonymous informants, 9 stakeholders were labelled as informant I to IX while the 10 beneficiaries of the intervention programs were also tagged as informant X to XIX. For the sake of emphasis, extensive responses by the informants were italicized and brief explanations were distinguished from the main discussion with quotation marks (APA, 2001). Emphasis for the interview was mainly on their perceptions on participation on the intervention programs and its impact on poverty reduction. For instance, informant I and III who are stakeholders of different intervention programs asserts that:

Participation of beneficiaries in the programs is eminent as the institutions utilizes the services of its Desk Officers and the traditional institutions (Emirate Councils through the District and Village Heads) to circulate information on the services and benefits of the program. Awareness is very important, because, limited access to information about any project, policy or program barred people from participating in it. We deem it pertinent to create awareness so as to break the barrier of development through political or ethnic differences (Informant I and VIII).

Upholding the above statement, an informant from Fadama III Coordinating unit stated that:

...participation of beneficiaries in Fadama III scheme is fabulous, as beneficiaries were at liberty to identify project(s) that are most beneficial to them, besides, they must reach a common agreement which must be formally documented and signed by their representatives (Informants III, VI, IX, and $\mathrm{XV})$.

In a similar view, another stakeholder of Fadama III (Informant II) program confirmed the above explanations that the program is a household name mainly in the rural areas of Niger state. Activities of this organization were made known through the communication unit, Desk officers in the Local Governments cum the traditional institutes across the state. "...Public awareness is one of the veritable tools to strengthening community interaction. By interaction I mean partaking and contributing idea in the policy/program..."

Certifying the stakeholders' sentiment, one of the beneficiaries of Fadama III program reveals that:

Fadama III program utilizes all possible avenues to educate us on their activities. Apparently, they are very liberal in terms of identification of felt-needs of the beneficiaries. We were occasionally invited to take part in various meetings and equally allow contributing our quota. Most of our contributions are reckoning with as they were implemented. In the Same vein, we also hold meetings at the local level to decide project to embark upon (Informant XIII).

During the Focus Group Discussion, it is remarkable to note that, informant XII proved the statements of the Fadama III stakeholders that "The services rendered to us are real pictures of what we need and presented to the unit. We intensely participate in the formulation and implementation of issues that affect our association and resolutions have not been changed". By implication, beneficiaries hold meetings to identify what they need most, endorse in writing and append their signatures for approval by the Fadama Coordinating unit.

The idea of Fadama III program was through radio. This motivated us to meet the Desk officer in the Local Government Area on the objectives of the program. The officer enlightens us on the benefits of the program and the processes to register and participate in it (Informant XI).

In addition, informants IV and V who are stakeholders in Niger state Commercial Agricultural Credit Scheme (NSCACS) shares similar view. They revealed that their organization take the issues of the beneficiaries with paramount importance. So:

.... awareness is an indispensable element to participation in decision making processes; but Niger state farmers have not been actively participating because they have no access to such vital information or because it is poorly circulated. To address this problem, NSCACS intensify sensitization on its new policies on agriculture to all nooks and crannies in the state to enable them actively participate in the program (Informant $V$ ).

According to Informant IV,

...one of the measures to subdue the increase of poverty is to create an enabling atmosphere for beneficiaries of this program (NSCACS) to participate in the policy formulation and implementation. To this end, we utilize the services of our Extension officers in the Local Government Areas to inform the target beneficiaries in the rural areas of the state on the activities of the scheme and to constantly 
invite them to our monthly meetings to deliberate subject that troubled them on our program.

In contrary to the above ideas by informants IV and $\mathrm{V}$, four informants unveiled that:

As far as NSCACS is concerned, our deliberations and contributions during our meetings are theoretically perfect, but in practice it has nothing to write home about. This is because our resolutions were not considered in the implementation process. Nonetheless, Fadama III program provided us with grant, allow us to identify our felt-needs, free hands to operate and to use our resources based on the approved specification (Informants XVI, XI, XVIII and XII).

Notwithstanding government policies to encourage citizen participation in decision-making, principally through decentralization policy, lack of information on important issues and lack of transparency and accountability of government officials represent major barriers to participation of citizens in the governance of Niger state and this ultimately affected poverty programs. This is very common with NAPEP that compiled our names for a proposed loan, unfortunately we were not invited when the loan was disbursed above all some few one invited were indoctrinated/brainwashed on issues to present in the floor of the meeting (Informant XV, XIV and XIII).

This concur with the view of (Njoh, 2003) that some forms of participation are time and again criticized as tokenistic, and indoctrinating the participants with little or no power and treating them as objects in 'self-help' schemes (Breitenbach, 1997; Njoh, 2003; Smith, 1998).

\section{CONCLUSION}

Using theory and empirical assessment, the study examines the impact of participation of the downtrodden on poverty intervention programs in Niger state rural area. The study adopts quantitative and qualitative analysis to cross-validate the findings. The quantitative result indicates significant relationship between participation of the downtrodden in policy initiation and poverty reduction. While the qualitative result reveals that participation is theoretically perfect and empirically faulty-it is elite dominating, as they provide downtrodden/beneficiaries with limited choice to influence the policy despite their involvement in policy process; consequently, most of the resolutions during their meetings neither reflected in the policy agenda nor implemented. Above all, participation is more of indoctrination particularly for NSCACS and NAPEP as some beneficiaries were brainwashed and spoon fed on issues to present during the meetings. Therefore, participation in this context is perceived as political gimmick, deceit, pretense, and mere formality than reality. Participation of the downtrodden in policy in this type of situation is not suffice to alleviate poverty, thus, this study recommends for the enactment of legal framework to empower an instituted advocacy group, featuring the Nongovernmental organizations (NGOs) in the like of Civil Society Organization (CSO) and dominant beneficiaries of intervention programs and stakeholders to checkmate the assume excessive power of all and sundry connected to the intervention programs.

\section{REFERENCE}

[1]. Aboh, C., \& Onabe, M. B. (2007). Extent of involvement of participants in the poverty eradication programme in Cross River state, Nigeria. Journal of Agriculture and Social Research (JASR), 7(2), 106113.

[2]. Ahmad, S., Abdullah, S. A. J., \& Arshad, R. B. (2015). Participation and Voting Policy Process in Nigeria: A Qualitative Study. Mediterranean Journal of Social Sciences, 6(4), 362.

[3]. Akinola, F. (2013). The Challenges of Agricultural Finance in Nigeria: Constraints to Sustainable Agricultural and Economic Revival. International Journal of Business and Social Research, 3(5), 234244.

[4]. Akpan, S. B., \& Udoh, E. J. (2016). Farmers' decision to participate in government agricultural programmes in a volatile political environment: a case study of farmers in the South-South region of Nigeria. Russian Journal of Agricultural and Socio-Economic Sciences, 53(5).

[5]. Al Attar, Z. H. (2015). A Case Study of IRADA: Its Impact on the Development and Enhancing the Legitimacy of Home-Based Businesses in Key Poverty Areas in Jordan.

[6]. Alejandro Leal, P. (2007). Participation: the ascendancy of a buzzword in the neo-liberal era. Development in practice, 17(4-5), 539-548.

[7]. Ameyaw, D., Kwame, \& Nyigmah, B., Justice. (2009). Localising and sustaining poverty reduction: experiences from Ghana. Management of Environmental Quality: An International Journal, 20(5), 490505.

[8]. Aminu, I., \& Onimisi, T. (2014). Policy Implementation and The Challenges of Poverty Alleviation in Nigeria. Academic Journal of Interdisciplinary Studies, 3(4), 295. 
[9]. APA. (2001). Publication manual of the American psychological association: American Psychological Association Washington, DC.

[10]. Bagozzi, R. P., \& Yi, Y. (1988). On the evaluation of structural equation models. Journal of the academy of marketing science, 16(1), 74-94.

[11]. Bawole, J., Nyigmah, \& Hossain, F. Marriage of the Unwilling? The Paradox of Local Government and NGO Relations in Ghana. International Journal of Voluntary and Nonprofit Organizations, 1-23.

[12]. Breitenbach, E. (1997). Participation in an anti-poverty project. Community Development Journal, 32(2), 159-168.

[13]. Brownhill, L., Moturi, T., \& Hickey, G. M. (2016). 9 Accountability and citizen participation in devolved agricultural policy-making. Food Security, Gender and Resilience: Improving Smallholder and Subsistence Farming, 140.

[14]. Burkey, S. (1993). People first: a guide to self-reliant participatory rural development: Zed Books Ltd.

[15]. Cain, B. E., Dalton, R. J., \& Scarrow, S. E. (2003). Democracy transformed?: Expanding political opportunities in advanced industrial democracies: Oxford University Press.

[16]. Cammack, P. (2004). What the World Bank means by poverty reduction, and why it matters. New Political Economy, 9(2), 189-211.

[17]. Cerna, L. (2013). The Nature of Policy Change and Implementation: A Review of Different Theoretical Approaches: OECD/CERI paper.

[18]. Chambers, R. (2002). Relaxed and Participatory Appraisal: notes on practical approaches and methods for participants in PRA/PLA-related familiarisation workshops: Participation Group, Institute of Development Studies, University of Sussex.

[19]. Cleaver, F. (1999). Paradoxes of participation: questioning participatory approaches to development. Journal of international development, 11(4), 597.

[20]. Cornwall, A. (2000). Beneficiary, consumer, citizen: perspectives on participation for poverty reduction: Sida Stockholm.

[21]. Cornwall, A., \& Brock, K. (2005). What do buzzwords do for development policy? A critical look at 'participation','empowerment'and 'poverty reduction'. Third world quarterly, 26(7), 1043-1060.

[22]. DFID. (2005). Growth and poverty reduction: the role of agriculture. London: DFID.

[23]. Domfeh, K., Ameyaw, Ahenkan, A., \& Bawole, J., Nyigmah. (2012). Is sustainable development achievable in Ghana? An analysis of Ghana's development policy achievements and challenges. International Journal of Environment and Sustainable Development, 11(3), 304-317.

[24]. Dreze, J., \& Sen, A. (1999). India: Economic development and social opportunity. OUP Catalogue.

[25]. Ephraim, C. (2013). Confronting the challenges and barriers to community participation in rural development initiatives in Duhera district, ward 12 Zimbabwe.

[26]. Etwire, P. M., Dogbe, W., Wiredu, A. N., Martey, E., Etwire, E., Owusu, R. K., \& Wahaga, E. (2013). Factors influencing farmer's participation in agricultural projects: the case of the agricultural value chain mentorship project in the Northern Region of Ghana. Journal of Economics and Sustainable Development, 4(10), 36-43.

[27]. Ferragina, E., Tomlinson, M., \& Walker, R. (2013). Poverty, Participation and Choice: The Legacy of Peter Townsend: Joseph Rowntree Foundation.

[28]. Ferrer, J. N. (2002). Revisioning transpersonal theory: A participatory vision of human spirituality: Suny Press.

[29]. Forae, O., \& Benedict, A. O. (2011). An Appraisal of Poverty Alleviation Programmes in Nigeria. JORIND, 9(1), 296-304.

[30]. Francis, P., \& James, R. (2003). Balancing rural poverty reduction and citizen participation: The contradictions of Uganda's decentralization program. World Development, 31(2), 325-337.

[31]. Hair, Ringle, C. M., \& Sarstedt, M. (2011). PLS-SEM: Indeed a silver bullet. Journal of Marketing theory and Practice, 19(2), 139-152.

[32]. Hair Jr, J. F., Hult, G. T. M., Ringle, C., \& Sarstedt, M. (2013). A primer on partial least squares structural equation modeling (PLS-SEM): Sage Publications.

[33]. Hickey, S., \& Mohan, G. (2004). 10 I Relocating participation within a radical politics of development: insights from political action and practice. Participation--From Tyranny to Transformation?: Exploring New Approaches to Participation in Development, 159.

[34]. Hickey, S., \& Mohan, G. (2005). Relocating participation within a radical politics of development. Development and change, 36(2), 237-262.

[35]. Idris, M., Nasiru, Rafee, M., M., \& Johar, F. (2011). Drought and desertification management in arid and semi-arid zones of Northern Nigeria. Management of Environmental Quality: An International Journal, 22(5), 595-611. 
[36]. Irvin, R. A., \& Stansbury, J. (2004). Citizen participation in decision making: is it worth the effort? Public administration review, 64(1), 55-65.

[37]. Jami, A. A., \& Walsh, P. R. (2014). The role of public participation in identifying stakeholder synergies in wind power project development: The case study of Ontario, Canada. Renewable Energy, 68, 194-202.

[38]. King, C. S., et al. (1998). The question of participation: Toward authentic public participation in public administration. Public administration review, 317-326.

[39]. Lewis, J. (2008). Children, changing families and welfare states: Edward Elgar Publishing.

[40]. Lowndes, V., \& Sullivan, H. (2004). Like a horse and carriage or a fish on a bicycle: how well do local partnerships and public participation go together? Local government studies, 30(1), 51-73.

[41]. Maiava, S. (1995). People's self-development: Perspectives on participatory action research: A journey through experience: Anisur Rahman, 234 pp., 1993, Zed Books, London, New Jersey, University Press Limited, Dhaka,£ 12.95 pbk,£ 32.95 hbk: Pergamon.

[42]. Mandal, P. K., \& Jirli, K. B. (2016). Role of Information and Communication Technologies in Rural Development. Journal of Global Communication, 9(conf), 147-151.

[43]. Michels, A., \& De Graaf, L. (2010). Examining citizen participation: Local participatory policy making and democracy. Local Government Studies, 36(4), 477-491.

[44]. Nielsen, e. a. (2008). Taxes and decision rights in multinationals. Journal of Public Economic Theory, $10(2), 245-258$.

[45]. Njoh, A. (2003). The role of community participation in public works projects in LDCs: The case of the Bonadikombo, Limbe (Cameroon) self-help water supply project. International Development Planning Review, 25(1), 85-103.

[46]. Nxumalo, K., \& Oladele, O. (2013). Factors affecting farmers' participation in agricultural programme in Zululand district, Kwazulu Natal Province, South Africa. J Soc Sci, 34(1), 83-88.

[47]. O'Toole, L. J. (2000). Research on policy implementation: Assessment and prospects. Journal of public administration research and theory, 10(2), 263-288.

[48]. Oakley, P. (1991). Projects with people: The practice of participation in rural development: International Labour Organization.

[49]. Obadan, M. I. (2001). Poverty reduction in Nigeria: The way forward. CBN Economic and Financial Review, 39(4), 159-188.

[50]. Okafor, N. (2015). The effect of poverty alleviation policies on community development: A focus on Obudu, Cross River state. Global Journal Applied, Management and Social Sciences, 10.

[51]. Olomola, A. (2013). Policy options for Agricultural nvestments and governance of markets.

[52]. Onyach-Olaa, M., \& Porter, D. (2000). Local government performance and decentralisation in Uganda: Implications for central governments and donors. Projet de document, photocopie.

[53]. Patel, S., \& Mitlin, D. (2002). Sharing experiences and changing lives. Community Development Journal, 37(2), 125-136.

[54]. Penderis, S. (2012). Theorizing participation: from tyranny to emancipation. Journal of African \& Asian Local Government Studies, 1(3).

[55]. Potts, M., Awuzie, B., McDermott, P., \& Stephenson, A. (2015). Engendering Change within a Water Infrastructure Client Organisation: A Participatory Action Research Approach. Journal of Engineering, Project, and Production Management, 5(2), 71.

[56]. Rahman, M. A. (1993). People's self development: Zed Books London.

[57]. Roy Kartik, C., \& Tisdell, C., Allan. (1998). Good governance in sustainable development: the impact of institutions. International Journal of Social Economics, 25(6/7/8), 1310-1325.

[58]. Scheingold, S. A. (2010). The politics of rights: Lawyers, public policy, and political change: University of Michigan Press.

[59]. Schofield, J. (2001). Time for a revival? Public policy implementation: a review of the literature and an agenda for future research. International journal of management reviews, 3(3), 245-263.

[60]. Sekaran, U., \& Bougie, R. (2014). Research methodology for business: New York: John Wiley \& Sons, Inc.

[61]. Selebalo, Q. C. (2001). Land Reform and Poverty Alleviation: Lesotho's experiences during the last two decades. Paper presented at the Regional Conference for Land Reform and Poverty Alleviation in Southern Africa.

[62]. Sen, A. (1999). Freedom as development: Oxford University Press, Oxford.

[63]. Siphuma, Z. R. (2009). An assessment of the role of public participation in IDP: The Thulamela Municipality. Stellenbosch: University of Stellenbosch.

[64]. Smith, B. (1998). Participation without power: Subterfuge of development? Community Development Journal, 33(3), 197-204. 
[65]. Thelma, M. N. (2015). Desertification in northern Nigeria: Causes and implications for national food security.

[66]. Tschirhart, C., Mistry, J., Berardi, A., Bignante, E., Simpson, M., Haynes, L., . . Robertson, B. (2016). Learning from one another: evaluating the impact of horizontal knowledge exchange for environmental management and governance. Ecology and Society, 21(2).

[67]. Zeldin, S., Camino, L., \& Calvert, M. (2007). Toward an understanding of youth in community governance: Policy priorities and research directions. Análise Psicológica, 25(1), 77-95. 